\title{
The essence of ilobolo and Zulu traditional marriage as depicted in Nelisiwe Zulu's literary work
}

\author{
Dr Sicelo Ziphozonke Ntshangase \\ University of KwaZulu-Natal, South Africa \\ Email: ntshangases2@ukzn.ac.za \\ Orcid number: https://orcid.org/0000-0002-8540-8413
}

\begin{abstract}
DOI : https://doi.org/10.46222/pharosjot.102.116

Two worlds exist, the seen and the unseen. Mortals or living beings populate the seen world and immortals or the living dead populate the unseen world. Through ilobolo (bride wealth) and traditional Zulu marriage, the two worlds are brought closer together by spilling an animal's blood and anointing the wedded couple with bile. This is a religious offering, inviting the ancestors of the wedded couple to bless the union. Ilobolo, in the space of the Zulu marriage, therefore, becomes a spiritual undertaking, warranting a deep understanding of Afrocentrism, which informs the philosophical and theoretical framework of this article. Through the lens of Afrocentrism, this article reports interpretively on how the Zulu people perceive ilobolo and marriage as two concepts connecting the seen and unseen worlds. The blood and bile of an animal are perceived as symbolic purifiers or religious cement gluing together the two families with their ancestors for eternity, because even death cannot tear them apart. In trying to understand how ilobolo and Zulu marriage and all the customs associated with these two concepts connect the seen and unseen worlds, the article draws its data from the novel, Umshado (Marriage, Wedding Ceremony) and the play, Isiko Nelungelo (Culture and Rights). Both these literary books were written by Nelisiwe Zulu, whose style of writing is always seen as interrogating the essence of Zulu culture and how it is perceived in modern times or post-1994 democratic South Africa.
\end{abstract}

Keywords: Afrocentrism; culture; ilobolo and marriage; living dead; seen and unseen worlds

\section{Introduction}

This article analyses the religious beliefs of the Zulu people and how ilobolo and marriage are used to connect the seen and unseen worlds. Zulu people have been chosen as a specific subject of this article because the two literary books, Umshado and Isiko Nelungelo, used as data sources, report on the Zulu culture. Both these books are fictional stories based on the real life situations of the Zulu people because they both depict how Zulu culture, specifically ilobolo and marriage, is portrayed and perceived in the post-colonial South African context (Zulu 2011a; Zulu 2011b).

Umshado is a novel, narrated by a third person narrator, with occasional dialogues among the characters, to add a dramatic flavour. Isiko Nelungelo is a drama story, with an overflow of dialogue among the characters, marked by few dramatic pauses where the third person narrator explains the actions and the feelings of the characters in brackets. A study by Hartung, et al. (2017)) indicates that whether the text is fictional or factual has no bearing on its significance because it is the perspective that matters, not factuality or the narration technique. These two fictional books, therefore were neither selected on the basis of factuality nor the narration approach but were chosen on how they relate to the real life situations of the Zulu people.

Zulu people believe in ancestry, which is a religious heritage deeply rooted in culture and follows the epistemological African worldview of the seen and unseen worlds (Mbaegbu, 2012). Humans 
or living beings populate the seen world, whereas ancestors or the living dead populate the unseen world (Mbiti, 1985). Mbiti (1985) coined the term 'living dead' to refer to the ancestors because of the religious belief by Africans in general, that those who have departed do not die but only transcend to a new place where they can see what transpires in both the seen and unseen worlds. For this article, the terms 'ancestors' and 'living dead' are used interchangeably to refer to the spiritual beings or what the Zulu people call amadlozi (Ntshangase, 2018a; Ntshangase, 2018b).

In the wider African communities, the ancestors are critical in the lives of the African people (Gbenda, 2006). Therefore, the Zulu people believe that ilobolo and marriage are sacred religious customs that cement or join the two families with their ancestors by spilling an animal's blood and anointing the wedded couple with bile (Posel \& Rudwick, 2014). The argument developed in the article is meant to answer the following questions that are closely intertwined.

1. What is the significance of ilobolo in connecting the seen and unseen worlds?

2. How are the concepts of marriage related to the religious philosophy of the Zulu people?

The two questions posed above are analysed using the interpretive paradigm, and the theory framing the argument is Afrocentrism. The interpretive paradigm and Afrocentrism are used to engage critically with the concepts of ilobolo and marriage, which are fundamental themes leading to a deeper philosophical understanding of Zulu communities regarding the issues of spirituality and divinity.

\section{Literature review}

As mentioned previously, ancestry is deeply rooted in culture. It is critical, therefore, that an explanation is provided as to how spirituality and culture connect. Therefore, the literature selected for this article is divided into two themes: the relationship between culture and the people following said culture, and the philosophical understanding of ancestry religion.

\section{The relationship between culture and people following it}

Note that people create culture, and as people evolve, so does culture (Amaegwu, 2013). Members of each ethnic group have a set of rules, values, customs, symbols, and traditions that are commonly accepted as a social identity defining the moral fibre of that community (Amaegwu, 2013). This is critical because it indirectly denotes that ilobolo and Zulu marriage, which are fundamental cultural concepts informing the argument of this article, as they are man-made, should evolve as culture and people evolve (Ntshangase, 2018a; Ntshangase, 2018b). In the past, for example, ilobolo was paid in cattle but now it is paid ether in cattle or money, or both, depending on the circumstances (Baloyi, 2015). As Zulu society evolves due to globalisation, ilobolo becomes commercialised and some families become greedy and charge ridiculous amounts of money and ilobolo is sometimes used by some unscrupulous men to treat women as their properties (Matope et al. (2013).

Zulu culture is embedded in the African worldview, which is based on the preamble of social cohesion, social wholeness, collective harmony (Mkabela, 2005). This idea of oneness is summarised in an isiZulu proverb saying that umuntu ngumuntu ngabantu (you are what you are because of others) (Zondi, 2013). Therefore, you only become a complete person because of your mutual coexistence with others (Sarpong, 2002). However, if the essence of oneness results in ill-treatment of women by men, the unity that is meant to be forged through marriage after ilobolo has been paid, may result in unending feud between the two families (Matope et al., 2013). This is possibly not something that I meant to address in this article but it is worth-mentioning that peace, harmony and social cohesion can only be attained if the bride is not abused because if she is, her family may not allow it to happen. This is confirmed by the isiZulu proverb saying alikho izinyane lemvubu eladliiwa yingwenya qede kwacweba iziziba (no crocodile will eat the 
baby of a hippo and the rivers stay calm) (Zondi, 2013). This simply means that when the family of the bride feel that their daughter is being ill-treated, they will obviously get furious and retaliate.

Ilobolo and Zulu marriage are therefore conceptualised and confined within the philosophical framework that wedded couples belong to their families and their families exist in a broader community with a set of cultural traditions handed down from generation to generation (Zulu 2011a; Zulu 2011b). Like any social belief system, the African indigenous knowledge system is not without flaws and some shortcomings are ignited by a lack of flexibility and transparency in how some customs are administered (Tanyanyiwa \& Chikwanha, 2011). Umshado and Isiko Nelungelo are two isiZulu books illustrating how the Zulu culture evolves as people evolve and how the lack of fluidity or flexibility in administering the cultural practices of ilobolo and Zulu marriage results in cognitive dissonance and resentment (Zulu 2011a; Zulu 2011b).

\section{Philosophical understanding of ancestry religion}

Mbiti (1991) presents three categories of African heritages: historical heritage, which analyses the African life in general; cultural heritage, which describes how African people behave and celebrate their physical and intellectual achievements; and religious heritage, which deals with matters of faith. Knoetze (2019) reports that it is not easy to draw a clear distinction between these three heritages because they are closely intertwined and can be better captured under a collective term, spirituality. Spirituality, however, is a broader term that does not necessarily address religion but rather the human quest for the philosophical meaning of life (Knoetze, 2019). The move from heritage to spirituality and then again from spirituality to religion can be tricky unless one understands the intricacies of African philosophy and cosmology, better explained by Mbiti (1991) as a way of thinking that sees religious heritage as an aspect of culture. It, therefore, is critical to emphasise that in this article, when such a quest explicitly narrates the mediation of the living dead with God on behalf of the living, then such heritage becomes religious (Amanze, 2011).

Zulu communities draw their religious faith or spirituality from the broader African religion named ancestry (Zulu 2011a; Zulu 2011b). Ancestry religion has been a permanent feature of the Zulu people because it brings them closer to the departed members of their families and the connection is revived by spilling blood of an animal and burning incense (Ntshangase, 2018a; Ntshangase, 2018b).

The offerings made by Zulu people to the ancestors are symbolic in a way that they metaphorically allude to "an endless cycle with the ancestors occupying a timeless, colourless and genderless place" (Edwards et al., 2011: 136). These offerings are contextually based mediations to celebrate significant family achievements, occasions, ceremonials, events such as birth and death and to incorporate the dead into the world of the living dead (Edwards et al., 2011). Ilobolo and marriage are examples of such communal contexts, where the families, their ancestors, and the community come together to celebrate love (Zulu 2011a; Zulu 2011b).

The Zulu people place ilobolo and marriage within the cultural context of the Afrocentric epistemological paradigm, where there is a symbiotic relationship or contact between the seen and unseen worlds (Baloyi \& Makobe-Rabothata, 2014). The living dead exist in the chain of life to bring protection to the living who honour them and wrath or agony to those who forsake them (Ntshangase, 2018a; Ntshangase, 2018b). The living dead must bless ilobolo and Zulu marriage because these immortal spiritual beings are critical at the beginning of life when the child is born, and the culmination of life, when a person passes on to the other world (King, 2013). The two concepts of ilobolo and Zulu marriage mark the beginning of a communal journey of wedded 
couples together with their families, ancestors, and the community, in reproducing life (Baloyi \& Makobe-Rabothata, 2014). It is imperative, therefore, that the ancestors are included when ilobolo and Zulu marriage are constituted because of the belief that the living dead are constantly present in the cosmological existence of the Zulu family's cycle and that they significantly influence the fortunes and misfortunes of the living (Ntshangase, 2018a; Ntshangase, 2018b).

\title{
Theoretical framework
}

The concepts of ilobolo and Zulu marriage are analysed with specific reference to the novel Umshado and the play Isiko Nelungelo through the lens of Afrocentrism, underpinning the theoretical framework of this article. Afrocentrism is deduced from the Afrocentric paradigm that gives the meaning of life, as experienced by Africans, through the philosophical and cosmological perspective of Africans themselves (Mkabela, 2005).

The intellectualisation of the Afrocentric paradigm is attributed to Asante (1987), whose view was that Africans should rediscover themselves by returning to the roots or source of their existence, which is pro- and pan-African. Marimba (2017) acknowledges that Africans must take pride in themselves; however, disagrees with Asante's terminology. His assertion is captured as follows:

\begin{abstract}
I have one small problem with Asante though-his use of the words 'regaining our platforms'-I do not agree that we need to regain anything because nothing was taken away. It is the African intellectual who is on the dock in the academy. The jury is out that we are guilty of appropriating western or Eurocentric worldviews on the African scene. By now, we should be stating that this or that is our ontological, cosmological, axiological, epistemological, or aesthetic stand and their basis as Africans, albeit in our multi-cultural nature. At least ubuntu cuts across many cultures and it may prove [sic] to be the unifying factor in a motley of concepts. When we accept our minds to be colonized [sic], even spiritually, we cannot turn back and mourn. It's a choice we made to accept Westernization [sic] in all its forms (Marimba, 2017: 200).
\end{abstract}

Marimba might be correct to claim that African scholars have allowed Eurocentric epistemologies to dominate them, but in the same vein, one must emphasise that a large pool of theories in academia exists that can be selected to frame our thoughts, whether Afrocentric or Eurocentric. The choice lies with us - if the theory is deemed fit in analysing societal issues.

Although Afrocentrism is a different viewpoint from Eurocentrism, note that the ideals of Afrocentrism supported in this article do not deny the people who subscribe to Eurocentrism the right to exercise their autonomy to do so (Chawane, 2016). Therefore, the theory of Afrocentrism that is open to the notion of a parallel coexistence of both Afrocentrism and Eurocentrism without any antagonistic polarisation and marginalisation of one by the other underpins this article (Marimba, 2017).

\section{Methodology}

Afrocentrism, as stated in the previous section, is the guiding theory framing the argument of this article. This theory is used interchangeably with the qualitative interpretive thematic analysis approach. The thematic analysis approach was selected for this article because the method assists in identifying, analysing, organising, interpreting, and reporting on themes that are found in the isiZulu books that were selected as the data sources for the article (Braun \& Clarke, 2006).

As an interpretivist, using the Afrocentric qualitative paradigm, I present and analyse the events 
narrated in the novel Umshado and the play Isiko Nelungelo by reporting on how their formalist structures, the plot, characterisation, viewpoints, and language are used to depict the essence of ilobolo and marriage on connecting the seen and unseen worlds. The main themes analysed in both books are ancestry religion, ilobolo, and Zulu marriage. These themes are analysed using Afrocentrism and the thematic analysis approach. The conceptualisation of the argument is in the Zulu community, post-apartheid South African context, where the Constitution accords both culture and religion equal recognition and protection (Department of Justice and Constitutional Development, 1996).

By using fictional stories as data sources, I am aware of the protocols of trustworthiness in qualitative research to be followed. Therefore, the formalist structures, plot, characterisation, viewpoints, and language of both books are presented verbatim and different literature is used to analyse them. Since the books are written in isiZulu, as the writer of the article, I first present direct quotations and translate each quotation into English before providing a full analysis. This is commissioned to guarantee the authenticity of the quote from the book and credibility of the analysis in relation to the Zulu culture, and to facilitate an understanding for readers who are not proficient in isiZulu.

\section{Findings}

The summaries provided below assist readers of the article to have, at least, a basic understanding of the contents of the books.

\section{Summary of Umshado}

The protagonist of this novel, Bhekani, has constant dreams of his late father, who asks him to get married soon to prolong the family's lineage. Bhekani's dilemma is that of all girlfriends he is currently dating, including Lindiwe, none are worth marrying. Every night, and sometimes during the day, Bhekani continues having the same dream. What makes matters worse is that now his late father becomes aggressive in these dreams, not only to Bhekani but also to his mother. Bhekani eventually falls in love with Tholakele, a widow who ran away from the village to live in the city to avoid being compelled to a levirate marriage with her late husband's brother, Bhatomu. Bhekani and Tholakele end up having a serious relationship resulting in Bhekani paying ilobolo for her. Bhekani continues having dreams of his late father chasing away the lady wearing inzilo, an attire worn by Zulu women when mourning for their late husbands. At the end of the novel, Tholakele avoids the cultural pressure of being forced into a posthumous marriage with Bhatomu.

\section{Summary of Isiko Nelungelo}

The protagonist of this play, Thenjiwe, is forced by her in-laws and biological parents into a levirate marriage with her late husband's brother, Dumisani. They argue that ilobolo was paid and that once a woman is married and introduced to the ancestors, there is no way that she can be allowed to go back home when the husband has passed on. Thenjiwe tries to reason with her in-laws and parents that times have changed and women nowadays have the right not to be forced into a posthumous marriage. However, nobody listens to her, except her sister, Nondumiso, and a male friend, Sipho, whom Thenjiwe has an eye on as a potential future husband. Unfortunately, Sipho is arrested for stabbing Dumisani while trying to protect Thenjiwe from being manhandled by him. Sipho eventually dies in prison and Thenjiwe is forced into a levirate marriage with Dumisani.

\section{Analysis of the books, Umshado and Isiko Nelungelo}

Both the literary books cover the themes of ancestry religion, ilobolo, and Zulu marriage, therefore 
closing the gap between fiction and reality because all these topics are pertinent to the real life of the Zulu people (Baloyi, 2015). The endings of these books are different, which is why I decided to analyse both instead of choosing one. The protagonist in the novel, Umshado does not allow culture to dictate to her who to love or marry (Zulu, 2011b). The protagonist in the play, Isiko Nelungelo, on the contrary finds herself with no choice but to conform to the cultural pressure to marry her late husband's brother, thus confirming that the lack of fluidity in administering culture may lead to cognitive dissonance and resentment (Zulu, 2011a).

\section{The significance of ilobolo in connecting the seen and unseen worlds}

The custom of ilobolo can be understood as pre-marriage discussions between the bride and groom's families, and it involves the groom's family to pay the bride's family in cattle or cash (Posel \& Rudwick, 2014). This custom is still practised in southern Africa where various names are used to refer to it, namely, ilobolo in isiZulu, roora in Shona, and bohali in Sesotho (Posel \& Rudwick, 2014). The isiZulu correct term is ilobolo not lobola. Lobola is a verb, referring to the action of paying ilobolo and linguistically, it cannot be used as a noun.

In this article, I analyse how ilobolo is used to connect the seen and unseen worlds. When Bhekani was preparing to send abakhongi (the negotiators) to pay ilobolo for Tholakele, his mother ensured that the living dead were informed.

Ubatshele-ke badlule lapha ukuze kushiswe impepho.

[Tell the negotiators to come here first so that we can burn incense.] (Zulu, 2011b: 61).

Kukhishwe imali ezizohamba nayo... Ibekwe phansi. Kushiswe impepho. Akhulume namadlozi unina kaBheki.

[They took out the money the negotiators were going to take with them and placed it on the floor.] (Zulu, 2011b: 63).

Uma kuya ngokuthi ufuna ukushada nalo mfelokazi ngempela, kuyomele uyoshisa impepho ucele kwabaphansi.

[If you are determined to marry this widow, I suggest that you burn incense and ask for the ancestors' blessings.] (Zulu, 2011b: 15).

The burning of incense has a religious meaning in Zulu communities because it is symbolically a channel by which they communicate with the living dead (Ntshangase, 2018b). Following the Afrocentric perspective, there is a need for Zulu people to communicate with the living dead because the living dead fully understand both the seen and unseen worlds, meaning that they have acquired the wisdom of both the worlds of mortals and immortals (Buthelezi, 2010). It, therefore, is imperative for Bhekani and his mother, as depicted above, to consult with the living dead before and when ilobolo is paid so that they bless the process.

Ilobolo, once paid, forms a permanent bond between the two families and ancestors, which is cemented with the spill of an animal's blood and anointing of the wedded couple with bile; therefore, Thenjiwe's father, Mondise, does not approve of her daughter coming back home following the death of her husband (Zulu, 2011a: 46):

Mondise: Ukubuya kukamakoti emendweni kusho ukuphindisela emuva amalobolo nakho konke okuthintene nawo.

[If a widowed bride leaves her marriage, it will mean that we must pay back the bride wealth and everything else paid by 
the in-laws.]

Thenjiwe is not allowed to go back home, not even by her biological father because of the Afrocentric belief that marriage does not culminate with the husband's death because a wife is never married to one person anyway, but to the entire family, including the ancestors (Ngidi, 2012).

\title{
How marriage is related to the religious philosophy of the Zulu people
}

The Afrocentric perspective teaches us that life does not culminate in death, as the living dead continue to influence the lives of the living in so many ways, including through the institution of marriage (Bond, 2011). The continuation of the chain of life and never-ending relationship between the living dead and living, through marriage, in particular, is emphasised in the novel, Umshado, which depicts the realistic philosophical and cosmological thinking of Zulu communities.

Ungakhoh/wa ukuthi umfazi owabadala akusiye owakho. Wena uyamletha kuphela. Uma bengamfuni ngeke ahlale nokuhlala lapha ekhaya.

[Do not forget that the wife you take is not necessarily yours, she belongs to the ancestors. Your role is to introduce her to them and if they do not approve the union, she will not stay in this family.] (Zulu, 2011b: 15).

\begin{abstract}
Waphupha uyise sengathi ungenisa abantu esangweni. Abanye uyabangenisa abanye uyabavimbela. Kuthe uma kufika intokazi yezingubo ezimnyama, wavimba uyise.

[Bhekani dreamed of his father standing at the gate. He was allowing some people to enter and chasing others away. When the woman in black clothes had a turn to enter, he chased her away.] (Zulu, 2011b: 69).
\end{abstract}

The concept of abadala can be loosely translated as the elders. However, in the context of the Zulu religion, which is deeply rooted in culture and the Afrocentric paradigm, abadala refers to ancestors (Zulu, 2011b). The ancestors are called the elders because they have closer contact with uMvelinqangi, The One Who Came First (God) and are wiser because they know the secrets of the unseen world and have lived in the seen world (Buthelezi, 2010). The Afrocentric paradigm, where marriage is a sacred rite of passage involving the whole community, influences the belief that the living dead play a major role in all aspects and phases of marriage (Ngidi, 2012; Ntshangase, 2018b).

The wedded couples are not only introduced to the family members living in the seen world but also to those who live in the unseen world. Zulu (2011a: 5-7) reports that once the introduction has been made, through slaughtering of an animal and smearing the wedded couple with bile, the union is sealed for eternity and not even death can break it:

MaMbatha: $\quad$ Phela umalokazane walapha ekhaya lo. Uhlanganiswe namadlozi akoNyamakayishi. Bangathini-ke bona esehamba kalula nje?

[This is our daughter-in-law. She was introduced to the Nyamakayishi [Zungu clan name] ancestors. What would they [the ancestors] say if she returns to her 


Original home as easy as that?]
Zunto esiqonde ukuyibeka kuwe koti ukuthi njengoba
sewabikwa emadlozini nje akuselula ukuba ubuye
uphume lapha ekhaya.
[What we are trying to say to you, daughter-in-law, is
that it is now impossible for you to leave this house
because you were introduced to the ancestors.]

Ngidi (2012: 49) vividly illustrates the idea of an inseparable bond, forged in marriage, through ilobolo and slaughtering of an animal and anointing the wedded couple with bile:

In African communities, as well as in Zulu communities, death does not constitute an end to a marriage. The paying of ilobolo and the slaughtering of the goat to accept the wife into the family is an eternal binding bond between the surviving spouse and the in-laws' family. When a husband dies, his brother has to take over all his wives and bear the responsibilities of a husband, taking care of his late brother's wives and children.

This quotation shows that the living must honour the wishes of the living dead, so that the living dead return the favour. This shows a mutual responsibility between those who live in the seen world and those who live in the unseen world. This mutual responsibility is emphasised even in the Zulu language, through the proverb saying izandla ziyagezana, literally translated to as hands wash each other (Zondi, 2013). The deeper meaning of this saying is that if you help me, I will return the favour (you scratch my back, I scratch yours). In an Afrocentric perspective, levirate marriage is not an oppressive practice for women but a spirit of ubuntu (humanity) where a brother looks after the interests of his late sibling (Baloyi, 2015).

\section{Discussion}

This article's findings reveal that ilobolo should be understood by all who practise it, including African Christians, through the lens of Afrocentrism because the concept of ilobolo cannot be defined using a western paradigm or Eurocentric perspective (Ngidi, 2012). Ilobolo, as a concept, has nothing to do with the Bible and cannot be associated with dowry or bride price regarding its religious and philosophical meaning (Ntshangase, 2018b). Ilobolo is a cultural practice, deeply rooted in African religious philosophy and cosmology, where the union of marriage involves the wedded couple, the two families, community, and the ancestors (Ntshangase, 2018b).

Ancestors are part of the family and community. Therefore, even before ilobolo negotiations commence, abakhongi will shout at the gate and call on the ancestral clan praises of that specific family to inform the ancestors that they are here to pay tribute to the family that has raised their potential bride and would seek the guidance of abadala (Zulu, 2011b). The ancestors of the two families should always be invited when ilobolo is paid to bless the union. Therefore, the bride and groom are smeared with the bile of an animal soon after ilobolo is paid to inform the ancestors, here are your children, please protect them (Zulu, 2011a).

The Zulu people, especially Christians, who reject some other Zulu cultures and embrace ilobolo have a deep psychological and philosophical short-sightedness when it comes to issues of African divinity and spirituality (Ntshangase, 2018b). They forget that long before the Bible was introduced in Africa, African people were religious (Ntshangase, 2018b). They believed in the existence of the Supreme Being who was in control of the universe and that the ancestors are the living dead who intercede on behalf of the living with the Supreme God, called uMvelinqangi (Ngidi, 2012). So, the modern Zulu people's selective acceptance of certain African belief systems, especially 
Christians, shows a deep sense of confusion, an emotional and psychological dissonance. If they reject Afrocentrism, they might as well change their surnames because a surname is also a cultural onomastic tradition linking that specific family with their ancestors (Baloyi \& MakobeRabothata, 2014).

\section{Conclusion}

In a democratic South Africa, section 9(3) of the Constitution acknowledges people's rights to religion, conscience, belief, and culture (Department of Justice and Constitutional Development, 1996). These rights, however, come with the responsibility to not infringe on other people's rights. The two books, Umshado and Isiko Nelungelo, that were selected as data sources for this article revealed that ilobolo and Zulu marriage have a deep philosophical meaning rooted in culture and ancestry religion.

Some people might think that by being born in a Zulu community, one is automatically inclined to believe in ancestry religion, which is proven wrong by the findings of this article. The article's findings reveal that ilobolo and Zulu marriage are concepts that cannot be divorced from the ancestry religion because they involve slaughtering an animal and anointing the wedded couple with bile. This is a religious practice associated with the veneration of the ancestors or the living dead to mediate with the Supreme Being on behalf of the living. The burning of incense is also a religious mediation ritual associated with ancestral religion. The article's findings reveal that once all these rituals have been performed, the Zulu marriage becomes an eternal bond that not even death can break.

Therefore, modern Zulu people, including Christians, must understand the essence of ilobolo and Zulu marriage to know the deeper meaning of these concepts. As the Constitution (1996) decrees, no one has the right to force his or her beliefs, religion, and culture on anyone. However, if one chooses to embrace these cultural practices, one must have a full comprehension of their essence. When one is aware of what the custom of ilobolo and Zulu marriage entails, one will not feel that the family, community, and ancestors are hard on them, as it happens in the two books, Umshado and Isiko Nelungelo.

\section{References}

Amaegwu, O.J. (2013). Globalization vs African cultural values. Enugu: Snaap Press Ltd.

Amanze, J.N. (2011). Contextuality: African spirituality as a catalyst for spiritual formation in theological education in Africa. Ogbomoso Journal of Theology, XVI(2), 1-24.

Asante, M. K. (1987). The Afrocentric idea. Temple University Press, Philadelphia.

Baloyi, L. \& Makobe-Rabothata, M. (2014). The African conception of death: A cultural implication. In L. T. B. Jackson, D. Meiring, F. J. R. Van de Vijver, E. S. Idemoudia, \& W. K. Gabrenya Jr. (Eds.), Toward sustainable development through nurturing diversity. Proceedings from the 21st International Congress of the International Association for Cross-Cultural Psychology. Available online at https://scholarworks.gvsu.edu/iaccp_papers/119/

Baloyi, M. E. (2015). The Christian view of levirate marriage in a changing South Africa. Journal of Sociology and Social Anthropology, 6(4), 483-491.

Bond, J.E. (2011). Culture, dissent, and the state: The example of commonwealth African marriage law. Yale Human Rights and Development Journal, 14(1), 1-59. 
Braun, V. \& Clarke, V. (2006). Using thematic analysis in psychology. Qualitative Research in Psychology, 3(2), 77-101.

Buthelezi, T. (2010). Sexuality and virginity testing in Zulu culture: Emerging issues. In C.O. Izugbara, C-C. Undie \& J.W. Khamasi (Eds.), Old wineskins, new wine: Readings in sexuality in sub-Saharan Africa (pp. 71-80). New York: Nova Science publishers.

Chawane, M. (2016). The development of Afrocentricity: A historical survey. Yesterday \& Today, No. 16, 78-99. DOI: http://dx.doi.org/10.17159/2223-0386/2016/n16a5

Department of Justice and Constitutional Development, Republic of South Africa. (1996). The South African Constitution. http://www.justice.gov.za/legislation/constitution/constitution.htm (Retrieved April 4, 2021).

Edwards, S.D. et al. (2011). Ancestral consciousness in the Zulu culture: A Wilberian view. Journal of Psychology in Africa, 21(1), 131-138.

Gbenda, J.S. (2006). African religion and Christianity in a changing world: A comparative approach. Chuka Educational Publishers, Enugu.

Hartung, F., Withers, P., Hagoort, P. \& Willems, R.M. (2017). When Fiction Is Just as Real as Fact: No Differences in Reading Behavior between Stories Believed to be Based on True or Fictional Events. Front. Psychol, 8(618), 1-14.

King, L. M. (2013). In discourse-towards a Pan-African psychology: Drum rolls for a psychology of emancipation. Journal of Black Psychology, 39(3):223-231.

Knoetze, J.J. (2019). African spiritual phenomena and the probable influence on African families. In die Skriflig, 53(4), 1-8.

Manganyi, J.S. \& Buitendag, J. (2013). A critical analysis on African traditional religion and the Trinity. HTS Teologiese Studies/Theological Studies, 69(1), 1-13.

Marimba, B.K. (2017). Revisiting the discourse on Afrocentricity and an Afrological method. European Journal of Social Sciences Studies, 2(5), 195-204.

Matope, N., Maruzani, N., Chauraya, E. \& Bondai, B. (2013). Lobola and gender based violence: Perceptions of married adults in Gweru urban, Zimbabwe. Journal of Education Research and Behavioral Sciences, 2(11), 192-200.

Mbaegbu C.C.A. (2012). Hermeneutics of God in Igbo Ontology. Awka: Fab Educational Books. Mbiti, J.S. (1985). African religions and philosophy. Heinemann Educational Publishers, Oxford. Mbiti, J.S. (1991). Introduction to African religion. (2nd ed.). Waveland Press, Long Grove.

Mkabela, Q. (2005). Using the Afrocentric method in researching indigenous African culture. The Qualitative Report, 10(1), 178-189.

Ngidi, E. B. (2012). The use of personal names in respect of the living dead within traditional polygynous families in Kwamambuli, Kranskop. Unpublished doctoral thesis. University of KwaZulu-Natal: South Africa.

Ntshangase, S.Z. (2018a). Men's perceived powers to destroy or rebuild women's lives: Analysis of gender stereotypes portrayed in Uthando Lungumanqoba. Educational Research for Social Change (ERSC), 7(2), 87-101.

Ntshangase, S.Z. (2018b). The power of dreams and religious philosophy of the Zulu people as portrayed in the novel, Umshado. South African Journal of African Languages, 38(2):237-245.

Posel, D. \& Rudwick, S. (2014). Marriage and Bridewealth (Ilobolo) in Contemporary Zulu 
Society. African Studies Review, 57(2), 51-72.

Sarpong, P. (2002). Peoples differ: An approach to inculturation in evangelization. Sub-Saharan Publishers, Legon, Accra, Ghana.

Tanyanyiwa, V.I. \& Chikwanha, M. (2011). The role of indigenous knowledge systems in the management of forest resources in Mugabe area, Masvingo, Zimbabwe. Journal of Sustainable Development in Africa, 3(3), 132-149.

Zondi, P.E. (2013). Siphuza Emthonjeni yokhokho. PEZ Publishers, Edendale.

Zulu, N. (2011a). Isiko Nelungelo. Eulitz, Arcadia.

Zulu, N. (2011b). Umshado. Afritude, Groenkloof. 